\title{
Increases in jellyfish biomass in the Bering Sea: implications for the ecosystem
}

\author{
Richard D. Brodeur ${ }^{1, *}$, Hiroya Sugisaki ${ }^{2}$, George L. Hunt $\mathrm{Jr}^{3}$ \\ ${ }^{1}$ Northwest Fisheries Science Center, National Marine Fisheries Service, Newport, Oregon 97365, USA \\ ${ }^{2}$ Tohoku National Fisheries Research Institute, 27-5 Shinhama-cho 3 chome, Shiogama, Miyagi, 985 Japan \\ ${ }^{3}$ Department of Ecology and Evolutionary Biology, University of California, Irvine, California 92697, USA
}

\begin{abstract}
There has been a dramatic increase in jellyfish biomass over the eastern Bering Sea shelf since the early 1990s, which was previously hypothesized to have been triggered by changing climate and ocean conditions. We examine the hypothesis that the presence of these large carnivores has affected fisheries resources, either through direct predation on larval stages, or through competition for zooplankton prey. In this paper, we explore the impact of this jellyfish increase on zooplankton and fish communities based on field data on the composition of the jellyfish community, and the abundance, size, stable isotopic signatures, and feeding habits of the principal scyphomedusae in the region. These data, together with those on zooplankton biomass, are used to estimate the ecosystem impacts of this increase. The center of jellyfish biomass has shifted from the SE Middle Shelf Domain in the early 1980s to the NW in the late 1990s. In recent years, the species composition of large medusae caught in trawls was dominated (>80\% by number and $>95 \%$ by weight) by the scyphozoan Chrysaora melanaster. Dense aggregations of this species occupied the water column in daytime between 10 and $40 \mathrm{~m}$. Their food habits consisted mainly of pelagic crustaceans (euphausiids, copepods, amphipods), although other jellyfish and juvenile pollock were also consumed. Based on stable isotope ratios, the trophic level of this scyphozoan is equivalent to, or higher than, that of Age 0 pollock. Preliminary estimates showed that medusae have a moderate grazing impact on zooplankton in the area around the Pribilof Islands; C. melanaster was estimated on average to consume seasonally about one-third of the standing stock and $4.7 \%$ of the annual production of zooplankton in this region. Daily consumption of Age 0 pollock was estimated to be $2.8 \%$ of the standing stock around the Pribilof Islands during 1999. A hypothesis for the increase in jellyfishes observed in the eastern Bering Sea, based on release from competition from planktivorous forage fishes, is proposed.
\end{abstract}

KEY WORDS: Jellyfish $\cdot$ Distribution $\cdot$ Food consumption $\cdot$ Ecosystem changes $\cdot$ Bering Sea

\section{INTRODUCTION}

In many of the world's oceans and seas, large gelatinous zooplankton such as scyphomedusae and hydromedusae represent a conspicuous component of the plankton, especially during the productive summer months. Over the last several decades, there has been a substantial interest in the role that these predatory

*E-mail: rick.brodeur@noaa.gov organisms play in marine ecosystems, especially their effects on lower trophic levels (Purcell 1992, 1997, Schneider \& Behrends 1994, Martinussen \& Båmstedt 1995, Omori et al. 1995, Pagès et al. 1996). Particular attention has been paid to cases where fish species of commercial importance were among the dominant prey consumed by gelatinous predators (Möller 1984, Purcell 1985, 1989, Arai 1988, Purcell \& Arai 2001). In some systems, cnidarians and other gelatinous zooplankters can account for a substantial proportion of the daily mortality of the early life stages of fishes (Arai 
1997, Purcell 1997). In addition to negatively affecting their prey populations, jellyfishes are also known to alter the seasonal cycle of plankton productivity (Huntley \& Hobson 1978, Feigenbaum \& Kelly 1984, Greve 1994). Owing to the potential impact jellyfishes have on marine ecosystems, there have been numerous attempts to quantify their consumption of zooplankton or ichthyoplankton, mostly in enclosed bays or seas (e.g. Fancett \& Jenkins 1988, Matsakis \& Conover 1991, Purcell et al. 1994, Behrends \& Schneider 1995, Omori et al. 1995, Berdnikov et al. 1999, Shiganova \& Bulgakova 2000). However, there have been surprisingly few estimates of their food consumption in or predatory impact on the major continental shelf regions of the world's oceans (Frank 1986).

The SE Bering Sea is an ecologically and economically productive ecosystem (National Research Council 1996), and has been the subject of several coordinated research efforts (Loughlin \& Ohtani 1999). The SE Bering Sea pelagic ecosystem has undergone dramatic changes over the last few decades (Hare \& Mantua 2000, Hunt et al. 2002, Schumacher et al. 2002). Two prominent changes include the increased dominance of walleye pollock Theragra chalcogramma, beginning in the late 1970s (National Research Council 1996), and the dramatic increase in large medusae biomass, starting in the late 1980s (Brodeur et al. 1999a).

The ecosystem impacts of the pollock increase have been examined elsewhere (Springer 1992), but the effects of the increase in jellyfishes have not been adequately assessed. Jellyfishes are known to be predators on larval fishes (Purcell 1985, Purcell et al. 1987, Purcell \& Arai 2001), which make them important in marine food webs. However, the trophic relationships between fishes and jellyfishes are poorly known in systems such as the Bering Sea, where the potential ecological impacts of the substantial increase in biomass of large jellyfishes are difficult to ignore (Brodeur et al. 1999a).

In this study, we examine the increase in jellyfish biomass and focus on the trophic relationships between walleye pollock and the dominant large scyphozoan jellyfish Chrysaora melanaster. We use data on its biomass, size, feeding habits, and stable isotopic ratios to estimate the trophic position and food consumption of $C$. melanaster relative to the amount of available prey. We also estimate the impact this jellyfish may have on pollock and zooplankton populations in the eastern Bering Sea, and we examine whether $C$. melanaster has an important role in the food web in the Bering Sea during summer.

\section{MATERIALS AND METHODS}

The biomass trend of gelatinous zooplankton caught as by-catch in survey bottom-trawl surveys that sampled the same set of stations each summer on the SE Bering Shelf from 1979 to 1997 was first presented by Brodeur et al. (1999a). In the present analysis, we extended the time series to 1999. We also added another year (1975) to the beginning of the series, which provides the only available estimate of jellyfish biomass prior to the well-documented 1977 regime shift (Hare \& Mantua 2000). Collections were made at each of 356 stations arranged in a grid pattern from June through August of each year. A $17 \mathrm{~m}$ wide trawl with graded mesh (10 cm at mouth to $3.8 \mathrm{~cm}$ at codend) was towed on the bottom for $30 \mathrm{~min}$. Catches of all large jellyfishes were weighed and standardized to $\mathrm{kg} \mathrm{ha}^{-1}$ (see Brodeur et al. [1999a] for details on abundance estimation). The total biomass was estimated for 8 major geographic regions, as defined by Hunt et al. (2002). Spatial differences in the distribution of jelly-

Table 1. Cruise statistics for summer and fall midwater collections of gelatinous zooplankton conducted during 1995-1999 and analyzed for abundance and size distributions

\begin{tabular}{|c|c|c|c|c|c|}
\hline Research vessel & Cruise & Dates & Gear & $\begin{array}{c}\text { No. } \\
\text { of collections }\end{array}$ & $\begin{array}{c}\text { Medusae } \\
\text { measured (n) }\end{array}$ \\
\hline \multirow[t]{2}{*}{ Miller Freeman } & \multirow[t]{2}{*}{ MF95-11 } & \multirow[t]{2}{*}{ 10-20 Sep 95} & Methot & 29 & 680 \\
\hline & & & Anchovy & 42 & 785 \\
\hline \multirow[t]{2}{*}{ Miller Freeman } & \multirow[t]{2}{*}{ MF96-13 } & \multirow[t]{2}{*}{ 11-25 Sep 96} & Methot & 28 & 400 \\
\hline & & & Anchovy & 27 & 1169 \\
\hline Oshoro Maru & 10M97 & 21-29 Jul 97 & Methot beam trawl & 28 & 427 \\
\hline \multirow[t]{2}{*}{ Miller Freeman } & \multirow[t]{2}{*}{ MF97-09 } & \multirow[t]{2}{*}{ 11-25 Sep 97} & Methot & 15 & 217 \\
\hline & & & Anchovy & 19 & 1667 \\
\hline Oshoro Maru & 1OM98 & 25-30 Jul 98 & Methot beam trawl & 27 & 379 \\
\hline Oshoro Maru & $10 M 99$ & 26 Jul-1 Aug 99 & Methot beam trawl & 20 & 586 \\
\hline Miller Freeman & MF99-09 & 12 Jun-25 Jul 99 & Methot & 29 & 634 \\
\hline \multirow[t]{2}{*}{ Miller Freeman } & \multirow[t]{2}{*}{ MF99-10 } & \multirow[t]{2}{*}{ 5-19 Sep 99} & Methot & 38 & 197 \\
\hline & & & Anchovy & 23 & 253 \\
\hline
\end{tabular}


fish biomass between the early and later part of the time series were compared using a Cramér-von Mises non-parametric randomization test (Syrjala 1996).

In addition to the bottom-trawl surveys, gelatinous macrozooplankton were also collected with a number of different quantitative midwater trawls between 1995 and 1999 (Table 1). Summer collections were made from 1996 through 1999 aboard the Japanese RV 'Oshoro Maru', which occupied a grid of stations on the outer shelf of the SE Bering Sea during the latter part of July. Large jellyfish were collected using a $5 \mathrm{~m}^{2}$ frame-trawl similar to that described by Methot (1986), with a net containing $2 \times 3 \mathrm{~mm}$ oval mesh in the body and $1 \mathrm{~mm}$ mesh in the codend. All tows were oblique to within $10 \mathrm{~m}$ of the bottom at an average ship speed of $6 \mathrm{~km} \mathrm{~h}^{-1}$ (Sugisaki et al. 1998). Collections were also made along transects in the vicinity of the Pribilof Islands aboard the NOAA RV 'Miller Freeman'. These collections were made each year between 1995 and 1999 using a Methot trawl. In addition, a $140 \mathrm{~m}^{2}$ anchovy trawl was used during September of 1995 to 1997 and 1999. Additionally, a Methot trawl was used during June and July of 1999 (Table 1). The Methot tows were oblique to within $5 \mathrm{~m}$ of the bottom, whereas the anchovy trawls were generally targeted on layers identified by acoustics. The anchovy trawl, which contained a large mesh size throughout the body of the net but included a $3 \mathrm{~mm}$ liner in the codend, caught substantial numbers of gelatinous zooplankton (Brodeur 1998). However, since it was not fished uniformly in the water column, we used it mainly to supplement the species composition and size-frequency distributions obtained from the Methot trawl, and it was not used to quantitatively estimate jellyfish biomass. The volume filtered by the Methot nets was estimated using calibrated flowmeters in the mouth of the net. Total wet weights of all large jellyfishes were measured for each haul. Bell diameters were measured on a subsample of the dominant species. During the fall sampling, the dominant medusa species were identified and counted. Although many small gelatinous zooplankton, including many ctenophores, were captured by the Methot gear (e.g. Sugisaki et al. 1998), we restricted our analysis to those medusae with bell diameters exceeding $40 \mathrm{~mm}$.

The vertical distribution of the dominant medusae were examined using a remotely operated vehicle (ROV) deployed at several locations around the Pribilof Islands in September 1997. Observations were made using a Hitachi CCD video color camera on a Super Phantom 2 ROV (see Brodeur [1998] for details). Observations of medusae were made only when the ROV was actively descending or ascending in the water column.
Samples for stable isotope analysis were collected at 5 stations during the September 1996 cruise of the 'Miller Freeman', and at 5 stations each in July 1997 and in July 1999 during cruises of the 'Oshoro Maru'. In 1997, 3 stations were from the NW Bering Sea (NWBS) south of St. Lawrence Island (Fig. 1). The remaining 2 stations in 1997 and all stations in 1996 and 1999 were in the SE region of the eastern Bering Sea shelf (SEBS). At the SEBS stations, larval and juvenile (Age 0) pollock, macrozooplankton, and Chrysaora melanaster were collected with the Methot frame-trawl. Immature and adult pollock were collected with a bottom trawl at 2 stations near St. Lawrence Island. Samples were frozen on board as quickly as possible. Dorsal muscle tissue of fish, umbrellar tissue of C. melanaster, and the whole body of other macrozooplankton were rinsed with distilled water, and dried in a $60^{\circ} \mathrm{C}$ oven on board just after catch.

Nitrogen and carbon isotope ratios were measured with an automated Europa Scientific 20-20 stable isotope mass spectrometer fitted with an element analyzer at Rutgers University, New Brunswick, New Jersey, and a Finnigan MAT 252 mass spectrometer at the National Research Institute of Fisheries Science in Yokohama, Japan. Isotope ratios are expressed as:

$$
\delta^{15} \mathrm{~N}\left({ }^{13} \mathrm{C}\right)=\frac{R_{\text {sample }}-R_{\text {standard }}}{R_{\text {standard }}} \times 1000(\% \text { ) }
$$

where:

$$
R={ }^{15} \mathrm{~N} /{ }^{14} \mathrm{~N}\left({ }^{13} \mathrm{C} /{ }^{12} \mathrm{C}\right)
$$

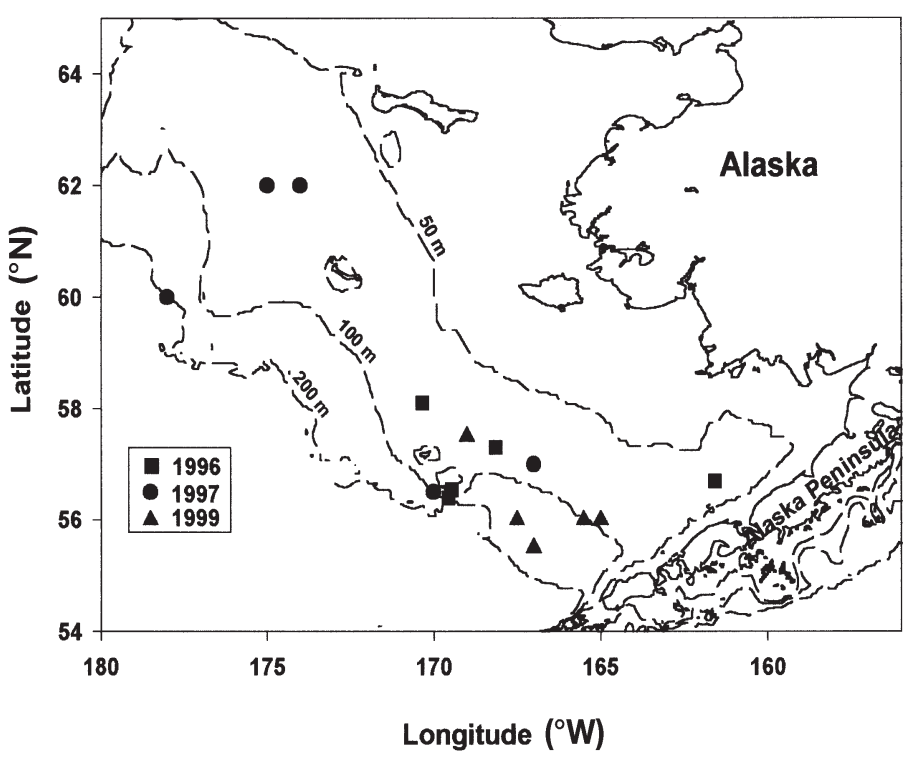

Fig. 1. Map of the study area and location of collections in 1996, 1997 and 1999 for stable isotope analysis 


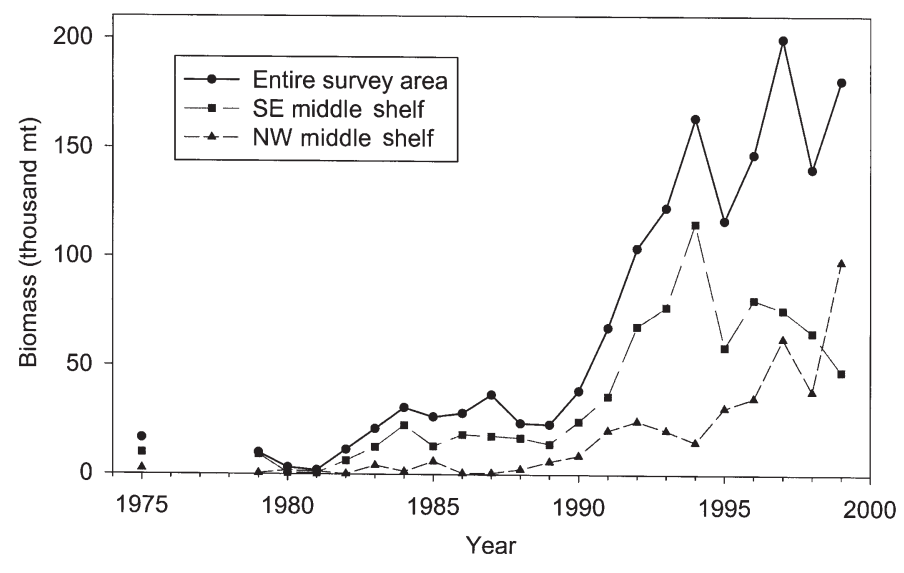

Fig. 2. Biomass (metric tons) of medusae collected in the total National Marine Fisheries Service (NMFS) sampling area during 1975 and from 1979 to 1999 on the eastern Bering Sea shelf. Also shown are the totals for the SE middle shelf and NW middle shelf only

Atmospheric nitrogen and PDB were used as the standards, and highly purified nitrogen gas and carbon dioxide gas were used as running standards. Precision of both instruments was within $0.2 \%$ for both $\delta^{13} \mathrm{C}$ and $\delta^{15} \mathrm{~N}$ analyses.

In addition to Chrysaora melanaster and Theragra chalcogramma, the isotope ratios of 3 species of hyperiid amphipods (Hyperia medusarum, Hyperoche medusarum and Themisto libellula), 2 species of euphausiids (Thysanoessa inermis and T. raschii), 1 copepod species (Neocalanus cristatus), and 3 species of hydromedusae (Catablema sp., Staurophora mertensii, and Aequorea forskalea) were also examined. The crustaceans and small medusae were grouped into larger taxonomic categories for analysis of their stable isotope ratios. Sample size varied from 5 to 25 individuals analyzed per taxa per year.
Stomach content analyses were made on a haphazard subsample of Chrysaora melanaster guts collected during the summers of 1997 and 1999 in the Methot beam trawls. Frozen specimens were brought back to the laboratory and measured. The gastric pouches were removed and examined under a dissecting microscope and all contents were identified to major taxonomic groups. In our analysis, the occurrence and number of major prey were estimated, and in some instances species identifications were possible. A possible bias in this analysis is that often the oral arm structure was missing or damaged by the trawling, potentially leading to underestimates of the amount of food eaten.

The role of jellyfishes as predators in the eastern Bering Sea shelf and slope was assessed on a daily and seasonal scale in the area around the Pribilof Islands. We used estimates of the pelagic biomass of Chrysaora melanaster collected in the 'Oshoro Maru' sampling during 1999. We converted these wet weights to carbon weights and then estimated food consumption using published values of daily ration to estimate daily and seasonally averaged food consumption rates. We then compared these consumption estimates with the available standing stocks of mesozooplankton in the area based upon NORPAC net (0.33 mm mesh) sampling at the same stations during the summer of 1999 from the 'Oshoro Maru' (Napp et al. 2002, N. Shiga, Hokkaido University, unpubl. data).

To estimate the consumption of walleye pollock by Chrysaora melanaster, we used density estimates of $C$. melanaster collected in the 1999 Methot trawls and the occurrence rate of pollock in their stomachs in 1999 to develop a daily consumption rate. These consumption estimates were then compared to the densities of juvenile pollock in the Methot trawls estimated from Methot trawls from the same locations.

Table 2. Species composition (percent of total) of the dominant gelatinous zooplankton collected during September 1995 to 1997 and 1999 near the Pribilof Islands in the anchovy and Methot trawls compared with surface counts taken in August 1982 from the SE Bering Sea shelf from the deck of a research vessel. -: not reported from surface observations

\begin{tabular}{|c|c|c|c|c|c|c|}
\hline Species & 1995 & 1996 & 1997 & 1999 & $1982^{\mathrm{a}}$ & $1982^{\mathrm{b}}$ \\
\hline \multicolumn{7}{|l|}{ Hydromedusae } \\
\hline Aequorea forskalea & 4.97 & 7.58 & 7.80 & 8.46 & 6.83 & 3.41 \\
\hline Ptychogena lactea & 0.84 & 2.80 & 0.32 & 0.02 & - & - \\
\hline Staurophora mertensii & 0.28 & 1.02 & 0.21 & $>0.01$ & 21.06 & 4.10 \\
\hline \multicolumn{7}{|l|}{ Scyphomedusae } \\
\hline Aurelia labiata & 0.56 & 3.89 & 0.64 & $>0.01$ & 9.39 & - \\
\hline Chrysaora melanaster & 91.04 & 82.54 & 83.45 & 88.51 & 42.12 & 86.35 \\
\hline Cyanea capillata & 1.68 & 1.85 & 7.59 & 2.98 & 20.60 & 6.14 \\
\hline Phacellophora camtschatica & 0.63 & 0.32 & $>0.01$ & $>0.01$ & - & - \\
\hline
\end{tabular}




\section{RESULTS}

\section{Biomass trends and distribution in summer surveys}

The catch of all medusae combined was less than $5.0 \times 10^{4}$ metric tons (mt) for 1975 and throughout the period 1979 through 1990. It increased dramatically in the early $1990 \mathrm{~s}$ and has averaged over $1.5 \times 10^{5} \mathrm{mt}$ since 1994 (Fig. 2). For most of the time series, the biomass was greatest in the southeastern middle shelf strata, but in more recent years, the contribution by the NW region has increased dramatically (Fig. 2). When examined on a smaller scale, most of the regions showed this increase, but the temporal sequence of change varied among regions (Fig. 3). The inshore and south middle shelf regions showed increases around 1990, but have experienced declines in recent years, whereas the NW regions, including the Pribilof region, began increasing several years later (Fig. 3).

This overall long-term change is clearly illustrated in plots of the geographic distribution of the catch in 1982 compared with that in 1999, the most recent sampling available (Fig. 4). The overall mean catch in 1982 was $0.230 \mathrm{~kg} \mathrm{ha}^{-1}(\mathrm{SE}=0.0619)$, with many ( $74.6 \%$ of total) zero catches. Higher concentrations of medusae were confined mainly to the southernmost part of the shelf. In contrast, during 1999, the mean catch of $4.213 \mathrm{~kg} \mathrm{ha}^{-1}$ (SE = 0.359) was almost 20 times higher. Relatively few $(15.3 \%)$ of the stations had zero catches and these were restricted mainly to the inshore and offshore stations (Fig. 4). Higher concentrations of medusae were found throughout the middle shelf but were more consistent in the NW region. This shift to the NW resulted in a significant $(p<0.001)$ difference in the spatial distribution between these 2 years.

The Chrysaora melanaster catch data from the 1998 and 1999 'Oshoro Maru' sampling were analyzed for interannual variability in biomass. Although stations did not overlap precisely for both years, much greater biomass was observed during 1999 than 1998 (Fig. 5). The median value for $1999\left(1.148 \mathrm{~kg} 10 \mathrm{~m}^{-2}\right)$ was significantly (Wilcoxon rank-sum test, $\mathrm{p}<0.001)$ higher than that in 1998 $\left(0.527 \mathrm{~kg} 10 \mathrm{~m}^{-2}\right)$.

\section{Species composition, size and biomass of jellyfishes}

The scyphomedusa Chrysaora melanaster dominated the large jellyfish catch ( $>80 \%$ of the total) during the fall surveys of 1995 through 1997 and 1999 (Table 2). Another scyphomedusa, Cyanea capillata, and the hydromedusa Aequorea forskalea were frequently present, but of lesser importance during all years. Although individual weights were not recorded every year, Chrysaora melanaster was generally the largest species caught in terms of biomass in 1997 and 1999 (Fig. 6), and its contribution to the total biomass was 93.5 and $99.0 \%$ in these 2 years, respectively. We also summa-
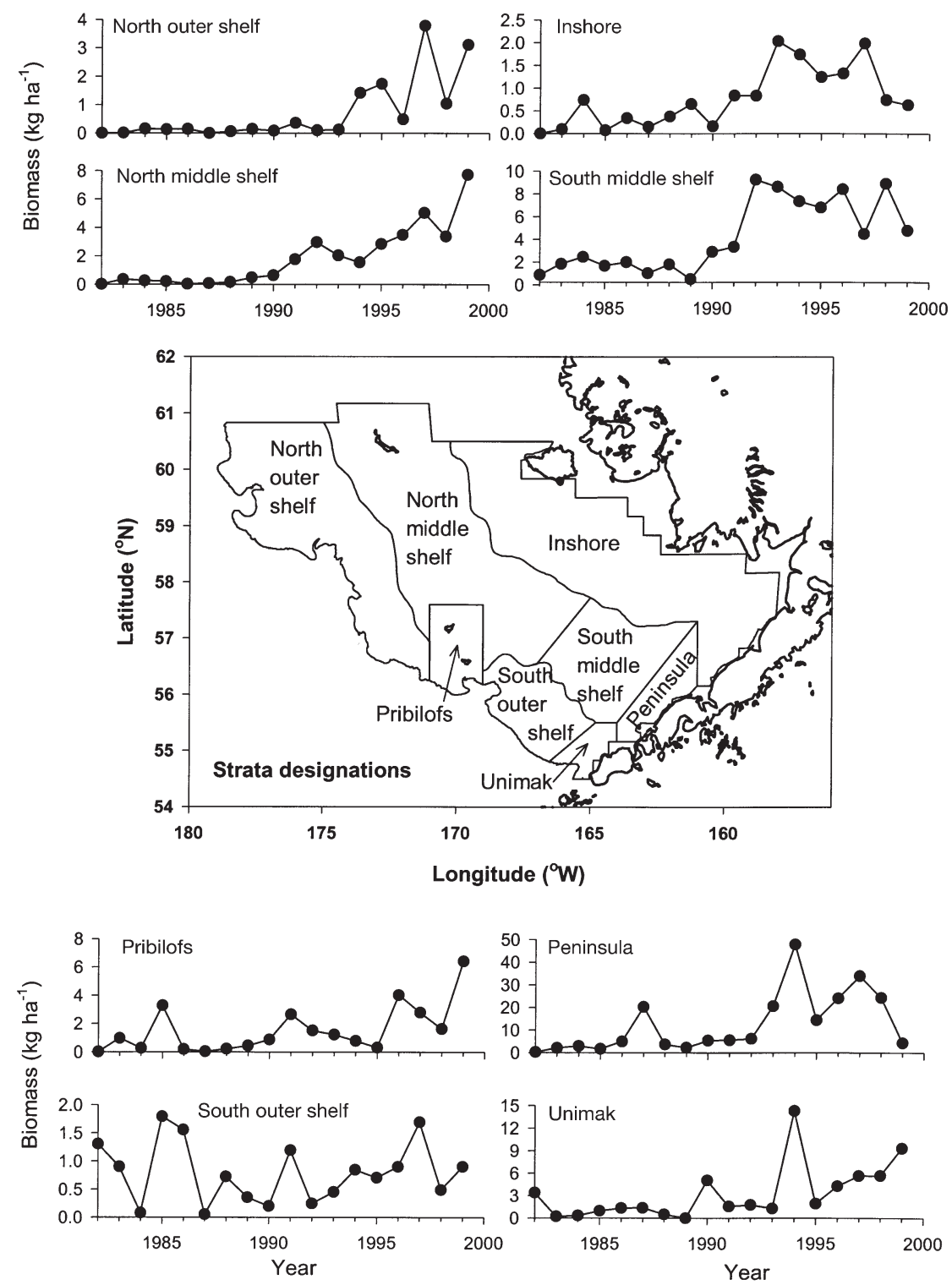

Fig. 3. Change in total jellyfish biomass for the 8 regions of the NMFS sampling area in the Bering Sea 


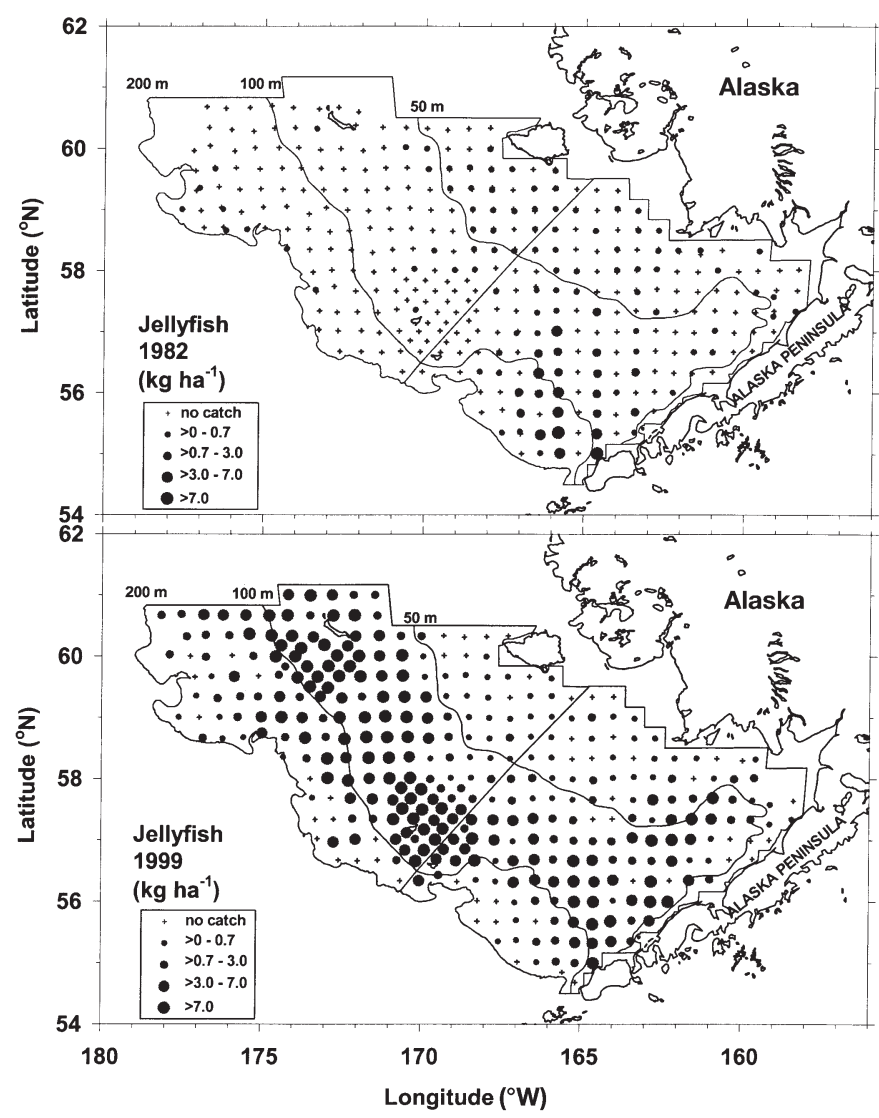

Fig. 4. Catch of total jellyfishes per station in the 1982 and 1999 NMFS survey

rized the only previous existing data on jellyfish species composition in the eastern Bering Sea based on surface observations collected during the PROBES study of 1982 (Hamner 1983). These data showed that $C$. melanaster was also important during this earlier time period (Table 2), but that its dominance was less striking (particularly in the data of Hamner \& Schneider 1986).

The vertical distribution of most of the dominant jellyfishes in the Bering Sea is poorly known. However, based upon observations by the ROV in 1997 (Fig. 7), it appears that peak densities of Chrysaora melanaster and the other large medusae are between 15 and $40 \mathrm{~m}$. Very few individuals were found at the surface, which suggests that surface observations or tows would underestimate the abundance of these species. Although the bottom depth varied (range 60 to $200 \mathrm{~m}$ ) among the ROV deployments, generally few individuals were found within $10 \mathrm{~m}$ of the bottom compared to the water column as a whole.
In summer sampling with only the Methot trawl, the dominant bell diameter mode was around $100 \mathrm{~mm}$ for all 3 years (1997 to 1999), but there were more large individuals caught in 1999. Some of this difference may be accounted for by the inclusion of the 'Miller Freeman' sampling in the summer of 1999 (Table 1) that occurred over a broader area of the shelf compared to the more limited 'Oshoro Maru' sampling in 1997 and 1998. Since we caught jellyfish using substantially different sized nets in different years during the fall sampling, we examined whether there were significant differences in the bell diameter size frequency of Chrysaora melanaster caught between the Methot and anchovy trawls. The anchovy trawl caught larger individuals (median $=210 \mathrm{~mm}$ ) than the Methot trawl $(180 \mathrm{~mm})$ in 1997, but the reverse was true in 1999 (220 vs $240 \mathrm{~mm}$ ), and overall there was no significant difference in the size distribution caught between the 2 gear types (Kolmogorov-Smirnov test, $\mathrm{p}=0.298$ ). Therefore, we combined size frequencies from both gears to examine interannual differences. In fall sampling around the Pribilof Islands with both the Methot and anchovy trawls, there was a broader range of bell diameters and several modes were present (Fig. 8). However, the 1997 median bell diameters were significantly smaller than in 1996 or 1999 (both p < 0.002).

\section{Stomach content data}

The stomachs of Chrysaora melanaster contained mainly crustaceans and gelatinous macrozooplankton and small fishes (Table 3). In both years, the highest frequency of occurrence of any crustacean group was that of euphausiids (mainly Thysanoessa inermis in

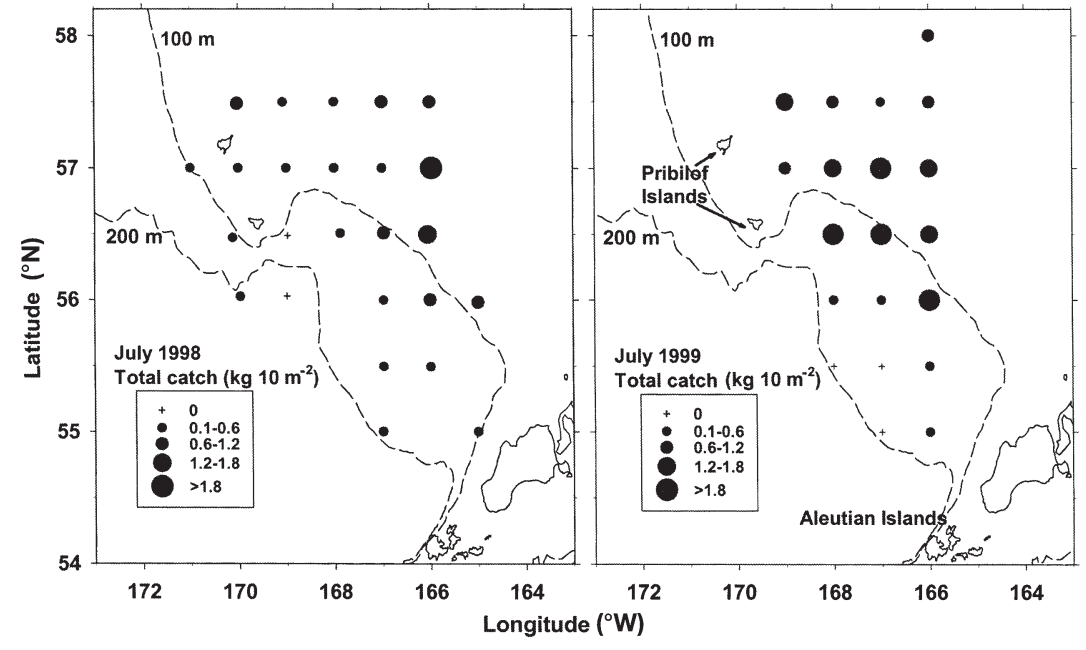

Fig. 5. Chrysaora melanaster. Catch per station in the 1998 and 1999 'Oshoro Maru' survey 


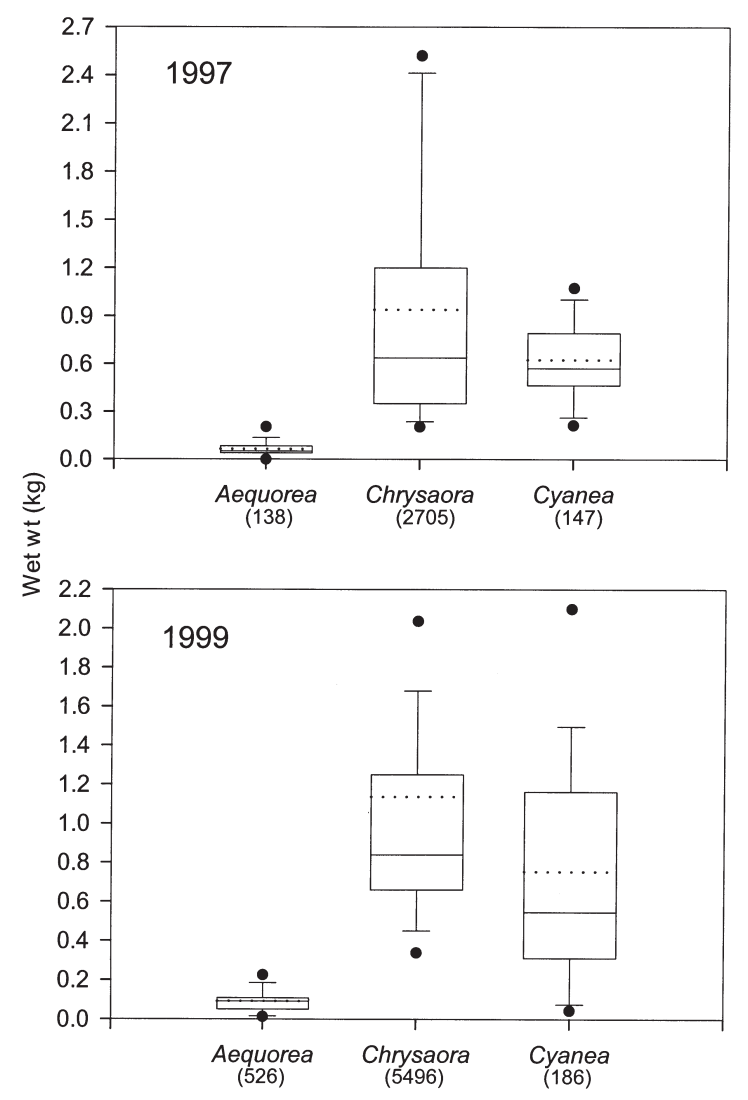

Fig. 6. Box-and-whisker plots of the weights of the 3 dominant medusae genera caught in midwater trawl surveys in September around the Pribilof Islands in the eastern Bering Sea. Continuous line inside the box is the median; upper (lower) box edges define the 75th (25th) percentiles of the data, whiskers are the 90th (10th) percentiles, and points the 95th (5th) percentiles; dotted lines are the means. Sample size is in parentheses below each genus name
Table 3. Chrysaora melanaster. Percent frequency of occurrence ( $\% \mathrm{FO}$ ) and percent of total number ( $\%$ no.) of major prey taxa found in the stomachs of individuals collected during the summer of 1997 and 1999

\begin{tabular}{|lccrr|}
\hline \multirow{2}{*}{ Prey taxa in stomachs } & \multicolumn{2}{c}{1997} & \multicolumn{2}{c|}{1999} \\
& \% FO \% no. & \% FO \% no. & \% \\
& & & & \\
\hline Unidentified gelatinous & 5.4 & 11.1 & 51.7 & 21.3 \\
zooplankton & & & & \\
Calanoid copepods & 16.7 & 15.6 & 34.5 & 13.8 \\
Hyperiid amphipods & 22.2 & 20.0 & 6.9 & 2.5 \\
Euphausiids & 61.1 & 44.4 & 41.4 & 31.3 \\
Decapod crab larvae & 0.0 & 0.0 & 17.2 & 6.3 \\
Larvaceans & 0.0 & 0.0 & 3.4 & 1.3 \\
Juvenile pollock & 22.2 & 8.9 & 17.2 & 21.3 \\
Unidentified juvenile fish & 0.0 & 0.0 & 6.9 & 2.5 \\
Unidentified remains & 27.8 & - & 17.2 & - \\
No. examined & 18 & 29 & & \\
No. empty & 2 & 1 & & \\
Bell diameter range (cm) & $11-40$ & $12-31$ & & \\
& \multicolumn{3}{c}{} \\
\hline
\end{tabular}

found in the stomachs (35 to $48 \mathrm{~mm}$ standard length), these juvenile pollock were approximately 80 to $110 \mathrm{~d}$ old (Brodeur et al. 2002).

\section{Stable isotope data}

Carbon isotope ratios of juvenile, immature and adult pollock, Chrysaora melanaster, small cnidarians and euphausiids ranged from -22.2 to $-17.8 \%$ (Figs. 9 \& 10), while the $\delta^{13} \mathrm{C}$ values of amphipods and copepods were lower (minimum values $<-24 \%$ ). The carbon isotope ratios of all groups were similar regardless of sampling areas in both 1996 and 1997. However, in 1999, the averaged value of carbon isotope ratio for
1997 and T. raschii in 1999), although copepods (Neocalanus spp. and Metridia spp.), hyperiid amphipods (Themisto libellula) and crab megalopae (Chionoecetes spp.) were also found in the guts. Gelatinous zooplankton, including unidentified gelatinous tissue and larvaceans, were found only in 1999. Juvenile pollock were found in stomachs in both 1997 and 1999, along with some well-digested larval and juvenile fish in 1999. In terms of number of prey eaten, euphausiids were the dominant taxa consumed in both years, although unidentified jellyfishes and juvenile pollock were also important in 1999 (Table 3). Juvenile pollock were found only in the stomachs of $C$. melanaster $>28 \mathrm{~cm}$ bell diameter. Based on the lengths of the intact pollock

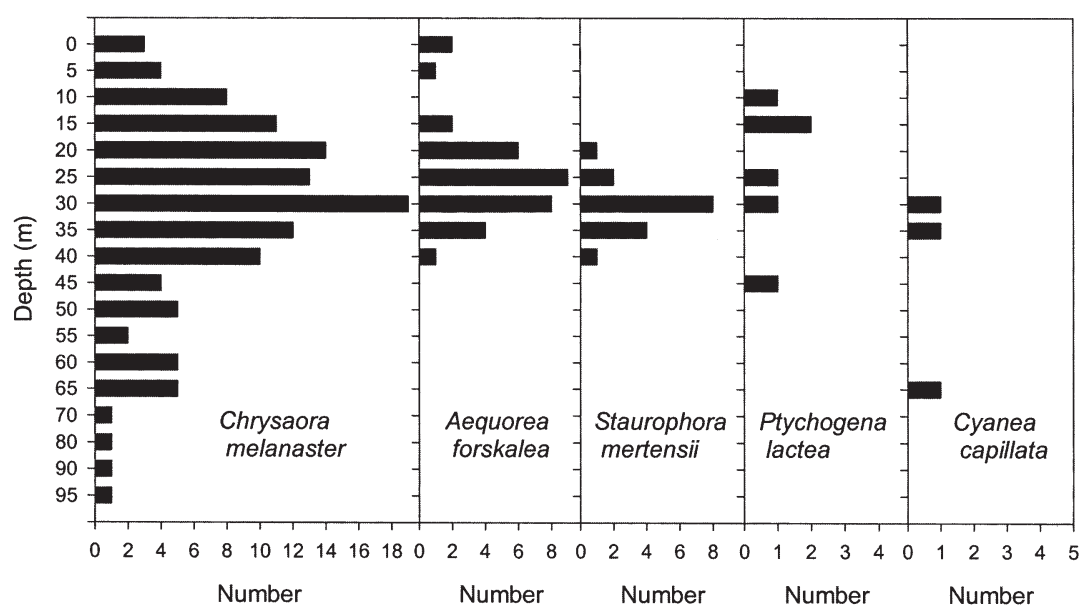

Fig. 7. Vertical distribution of the dominant jellyfish species observed in ROV (remotely operated vehicle) dives around the Pribilof Islands in September 1997 by $5 \mathrm{~m}$ depth intervals. Day and night observations combined 


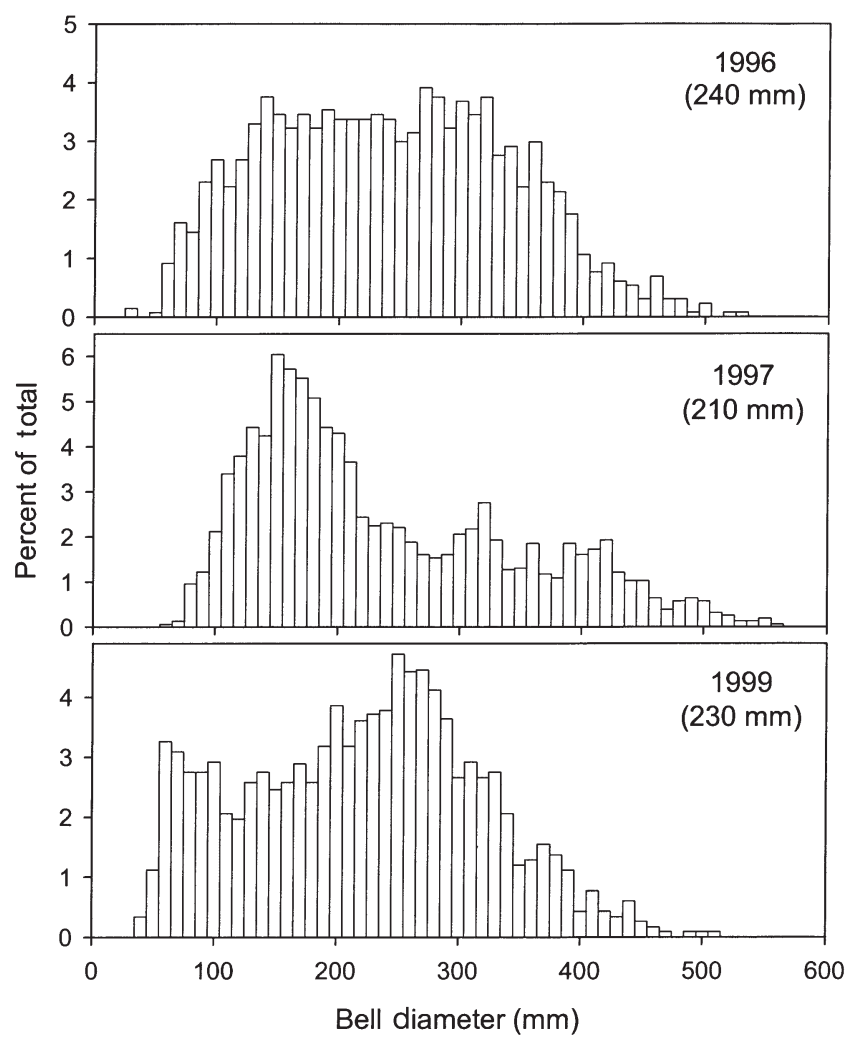

Fig. 8. Chrysaora melanaster. Bell diameters of specimens collected in the Methot and anchovy trawls during September 1996, 1997, and 1999. Median diameters are shown in parentheses for each year

every group varied from $1.0 \%$ (euphausiids) to $2.4 \%$ (copepods), higher than values for the same groups collected in 1996 and 1997. The highest value examined in this study was $-17.9 \%$ for euphausiids collected in the SEBS.

The nitrogen isotope ratio of each group was also similar regardless of areas, both in 1996 and 1997 (Figs. 9 \& 10). In the NWBS area in 1997, the highest $\delta^{15} \mathrm{~N}$ groups in this study were adult and immature (Age 1+) pollock. Chrysaora melanaster had as high or higher $\delta^{15} \mathrm{~N}$ values than Age 0 pollock in all years and regions and especially in 1996, and the values were significantly higher than those of small cnidarians, euphausiids, and copepods. At the SEBS stations, the $\delta^{15} \mathrm{~N}$ values of C. melanaster were higher than that of small hydromedusae and crustacean macrozooplankton in every year. The $\delta^{15} \mathrm{~N}$ values of euphausiids and amphipods were higher than those of copepods. In 1999, averaged $\delta^{15} \mathrm{~N}$ values of all groups examined were consistently higher than the values of the same groups collected in 1996 and 1997. The differences in these values ranged from $0.9 \%$ for amphipods to $2.7 \%$ for copepods.

\section{DISCUSSION}

\section{Changes in biomass and distribution of jellyfishes}

Evidence that gelatinous zooplankton biomass is increasing in a number of regions around the world is accumulating (Mills 1995, 2001). In some systems which have experienced burgeoning populations of jellyfishes (e.g. Chesapeake Bay, northern Adriatic Sea, Gulf of Mexico), it is suspected that anthropogenic forcing (i.e. nutrient loading and over-harvesting) has contributed to the outbreaks (Purcell et al. 1999, Graham 2001). In other cases such as the Black Sea, introduced species, which may lack natural regulation, have been implicated (Zaitsev 1992, Mills 1995, Shiganova 1998). Such increases may translate into substantial economic impacts in terms of lost tourism or
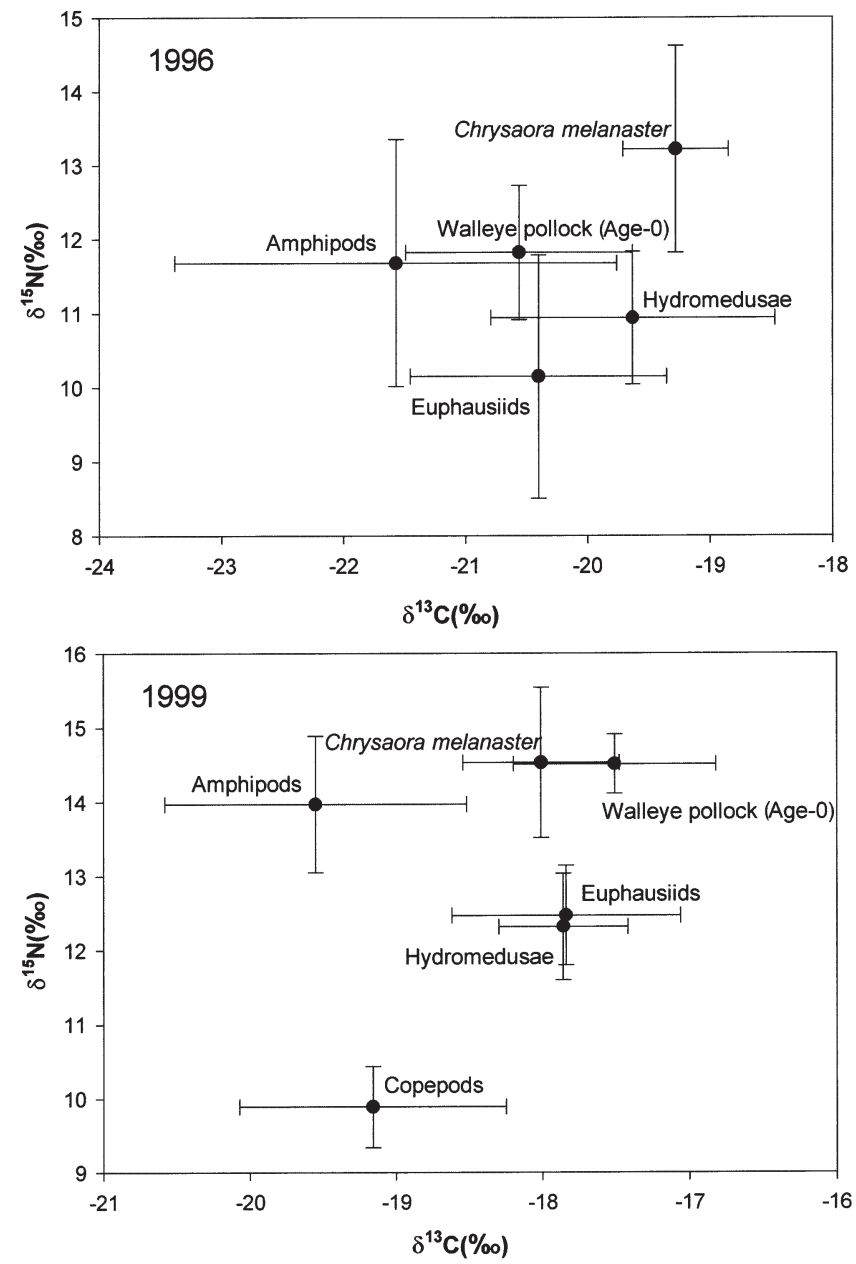

Fig. 9. Plots of $\delta^{13} \mathrm{C}$ versus $\delta^{15} \mathrm{~N}$ for 1997 'Oshoro Maru' collections from the NWBS (NW Bering Sea) and SEBS (SE Bering Sea)(see Fig. 1 for collection locations). Points are mean values for each measurement and error bars represent $1 \mathrm{SD}$ of the mean 
fisheries yield. For the Bering Sea, the data presented here show that the biomass of jellyfishes apparently indigenous to the eastern Bering Sea has increased greatly, particularly over the past decade.

Our estimates of the biomass of jellyfishes in the eastern Bering Sea are almost certainly conservative. Visual observations from 1997 presented here and earlier observations in 1995 (Brodeur 1998) suggest that the bulk of the Chrysaora melanaster biomass is found in midwater, often near the pycnocline. This substantiates the argument that the NMFS summer bottomtrawl sampling catches jellyfishes mainly during deployment and retrieval of the net. Thus in all years, the actual biomass of jellyfishes present in the water column is grossly underestimated. For example, if we expand our biomass estimate of jellyfishes from the summer pelagic trawl survey conducted by the 'Oshoro Maru' in 1999 to the entire survey area in Fig. 4, we arrive at $56 \times 10^{6} \mathrm{mt}$, substantially higher than the $18 \times 10^{4} \mathrm{mt}$ estimated for the entire NMFS 1999 survey. Although it is possible that the 'Oshoro Maru' sampling took place in an area of unusually high biomass, we maintain that the bottom trawl is not an efficient sampler of jellyfishes in the water column and therefore underestimates the true biomass present. Thus, the abundance data we present from these NMFS surveys may only be indicative of a trend, rather than absolute estimates of abundance.

In addition to the rapid increase in jellyfish biomass in the 1990s, there has been a redistribution of biomass within the eastern Bering Sea shelf. In the 1980s, the main concentrations of jellyfishes were found in the SE margin of the Bering Sea along the Alaska Peninsula (Brodeur et al. 1999a). Biomass in some areas, such as the 'Slime Bank' north of the Alaska Peninsula, was so high that fishing vessels shunned the area completely to avoid clogging their nets with medusae. In the 1990s, and particularly since 1995, there has been a gradual movement of the center of jellyfish biomass to the NW and to deeper parts of the shelf, although the majority of the biomass is still restricted to the middle shelf domain. Based on high catches at the northern extremity of the NMFS sampling grid in recent years, it is likely that the distribution of jellyfishes has extended farther north outside our sampling area, where the prevailing currents flow. There is no apparent biomass peak at the shelf break, despite the high productivity found in this region (Springer et al. 1996).

\section{Trophic relationships of Chrysaora melanaster}

Diet data from this jellyfish collected in 1997 and 1999 suggest that, in addition to other medusae and crustacean zooplankton, juvenile walleye pollock com- prise an important part of the diet of Chrysaora melanaster. The only previous study of the food habits of C. melanaster was that of Hamner (1983) based upon examination of 28 individuals collected from the surface at 1 station. In that study, Hamner also found evidence of predation on juvenile walleye pollock similar to that found by us. However, the pteropods Limacina spp. comprised the numerically dominant prey taxon identified in this earlier study. Pteropods were not consumed in our study, although they are common in the plankton around the Pribilof Islands (Brodeur et al. 2002). Since Limacina spp. have a rigid shell, it is unlikely that they would have been overlooked unless they were fairly well digested. Other major prey taxa that we identified, including euphausiids, amphipods, copepods and crab larvae, were also present in the Hamner study.
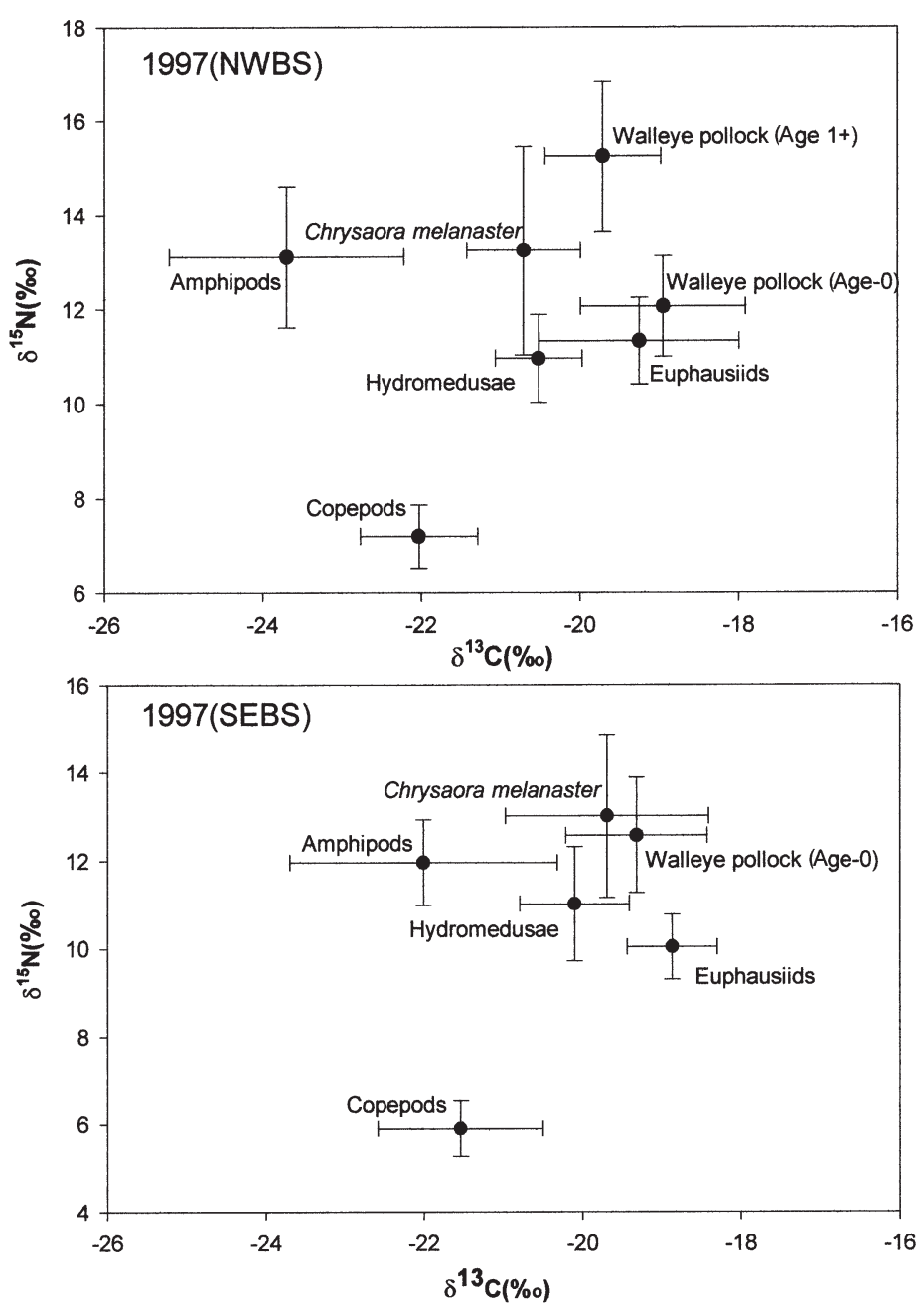

Fig. 10. Plots of $\delta^{13} \mathrm{C}$ versus $\delta^{15} \mathrm{~N}$ for $1996 \mathrm{NMFS}$ and 1999 'Oshoro Maru' summer collections from the SEBS (see Fig. 1 for collection locations). Points are mean values for each measurement and error bars represent $1 \mathrm{SD}$ of the mean 
Our Chrysaora melanaster feeding data are consistent with previous studies on congeners in other systems (summarized by Arai 1997). For example, $C$. quinquecirrha collected in Chesapeake Bay showed positive selection for small prey such as copepods, but were able to consume a wide variety of prey items including larval fishes (Purcell 1992). However, the persistent occurrence of euphausiids in the diets of $C$. melanaster in the Bering Sea is somewhat surprising, since euphausiids are seldom reported in other studies (Arai 1997). Although some euphausiids may have been ingested during the capture process during the 1997 and 1999 sampling, many of the euphausiids were well digested, suggesting that ingestion had occurred some time before capture. Moreover, the mesh size of the codend of the trawls precludes retention of these small euphausiids, suggesting that the opportunity for net feeding was minimal. This potential source of error was not present in Hamner's (1983) study, as he dip-netted individual jellyfish from the sea surface.

Once established, jellyfishes can apparently outcompete fish populations because many jellyfishes have higher consumption rates, respond more rapidly to pulses of food than their competitors, and have the potential to prey upon the early life stages of many fishes (Purcell et al. 1999, Purcell \& Arai 2001). Purcell \& Sturdevant (2001) examined diets of jellyfishes and pelagic juvenile fish species in Prince William Sound, Alaska, an ecosystem at the same latitude and somewhat similar to the eastern Bering Sea. Diet overlap, and hence the potential for competitive interactions, was high between the medusae and fishes such as juvenile walleye pollock, Pacific herring Clupea pallasi, and Pacific sand lance Ammodytes hexapterus, all common species in the Bering Sea. Age 0 pollock have been shown to belong to the same pelagic assemblage as jellyfishes in the Bering Sea, and show a high spatial overlap (Brodeur et al. 1999b), thus facilitating potential trophic interactions. However, some juvenile fishes including walleye pollock may derive benefit from the presence of large Chrysaora melanaster and other jellyfishes by taking refuge among their tentacles during the daytime (Brodeur 1998), and thus possibly avoid some predation. It seems likely, however, that pollock are more adversely affected by large spring and summer populations of jellyfishes because of their potential for competition or predation.

The ratios of the stable isotopes of nitrogen and carbon in an organism can be used as a method to establish its position within a food web. Because elements such as carbon and nitrogen within an animal's body are derived from their food, the isotope ratios of these elements reflect the isotope ratios of their prey. The stepwise increase in the nitrogen-stable isotope ratio with increasing trophic level has been well documented (reviewed by Michener \& Schell 1994). Usually, the $\delta^{15} \mathrm{~N}$ value of a predator is 3 to $4 \%$ higher than that of its prey. Therefore, the nitrogen isotope ratio is a parametric indicator of the trophic distance between organisms in food chain. Generally, the carbon isotope ratio of an animal's body is similar (within 1 to $2 \%$ ) to that of its food (Michener \& Schell 1994) because this value originates from the value of the primary producer in the food chain.

We found that the $\delta^{13} \mathrm{C}$ values of copepods and amphipods were lower than that of other macrozooplankton examined. The differences in $\delta^{13} \mathrm{C}$ values may reflect differences in the lipid content of the different organisms. It is known that $\delta^{13} \mathrm{C}$ values of lipids are lower than those of other tissues (DeNiro \& Epstein 1977, McConnaughey \& McRoy 1979), and organisms whose lipid contents are high generally show low delta carbon isotope ratios. Cold-water species of copepods generally show higher lipid content than other macrozooplankton, such as chaetognaths and euphausiids, in the north Pacific (Omori 1969, Ikeda 1974). Therefore the low $\delta^{13} \mathrm{C}$ values of copepods may be associated with high lipid content.

Because their carbon isotope ratios were similar, we hypothesize that Age 0 pollock, small hydromedusae, and euphausiids belong to the same food web as Chrysaora melanaster, both in the NWBS and in the SEBS. Moreover, the trophic level of C. melanaster is generally lower than that of adult pollock, but was in some years higher than Age 0 pollock. The $\delta^{15} \mathrm{~N}$ values of $C$. melanaster were less than $1 \%$ below those of adult pollock, whereas the differences in $\delta^{15} \mathrm{~N}$ values between $C$. melanaster and Age 0 pollock ranged from 0.02 to $1.4 \%$. The high trophic level of $C$. melanaster is corroborated by the diet data, since some digested euphausiids, small jellyfishes and juvenile pollock were found in their stomachs. Therefore, $C$. melanaster potentially compete for food with older pollock. As is the case with pollock, there is likely to be some increase in isotopic ratios with increasing size of the medusae (Malej et al. 1993).

Schell et al. (1998) analyzed the distribution of the carbon and nitrogen isotope ratios of zooplankton throughout the Bering Sea over an extended time period. Their results may be considered as standard values for the Bering Sea. Their sampling area was divided into 11 subregions based on water-mass characteristics. According to their subregions, our sampling area of SEBS was located in their eastern Bering Sea and our NWBS was located in their central Bering Sea. Their carbon and nitrogen isotope values of euphausiids collected in the eastern Bering Sea were similar to values for samples collected in our study in the SE Bering Sea in 1996. In 1997, however, our mean 
$\delta^{13} \mathrm{C}$ values for euphausiids were higher than those of Schell et al.'s results in both the central Bering Sea (NWBS) and eastern Bering Sea (SEBS). Moreover, in 1999 the differences between our results and those of Schell et al. were even greater than in 1997. This suggests that primary production from 1997 through 1999 was anomalous, perhaps resulting from the extensive coccolithophore blooms during the summers of these 3 years (Napp \& Hunt 2001, Stockwell et al. 2001).

The coccolithophore blooms may have influenced stable isotope ratios in the ecosystem by 1 of 2 mechanisms. First, high growth rates of phytoplankton lead to high $\delta^{13} \mathrm{C}$ values (Fry \& Wainright 1991), and high rates of primary production were measured around the periphery of the coccolithophore bloom (Stockwell et al. 2001). Although not measured, it is likely that the $\delta^{13} \mathrm{C}$ ratios of the coccolithophores were also high. Second, the number of trophic levels between the coccolithophores and consumers such as euphausiids or Chrysaora melanaster may be greater than for diatoms, the usual dominant primary producers in the Bering Sea. Since coccolithophores are smaller than diatoms, herbivores that consume coccolithophores might also be expected to be small (Olson \& Strom 2002). The number of trophic levels between primary producers and secondary consumers such as euphausiids or C. melanaster should be higher in a coccolithophore-dominated system than in a diatom-domi- nated ecosystem. Thus the trophic level of an organism increases when coccolithophores are the main primary producers. Smith \& Heinrichs (2002) also found anomalously high $\delta^{13} \mathrm{C}$ and $\delta^{15} \mathrm{~N}$ values in plankton and sediment trap samples collected in 1999 compared to 1997 and 1998, which they attributed to the early and prolonged coccolithophore bloom in 1999. Schell et al. (1998) concluded that assessing trophic levels of top consumers must be done cautiously, because the natural range of isotope ratios can be very large.

\section{Consumption of zooplankton and pollock}

Zooplankton consumption by Chrysaora melanaster was estimated for the area around the Pribilof Islands over a $90 \mathrm{~d}$ summer period in 1999. We estimated that this species alone consumed an average of $31.9 \%$ (95\% CI from 13.8 to $50.1 \%$ ) of the zooplankton standing stock and $4.7 \%$ (CI from 2.0 to $7.3 \%$ ) of the annual secondary production (19 $\mathrm{g} \mathrm{C} \mathrm{m}^{-2} \mathrm{yr}^{-1}$ : Springer et al. 1996) of the middle shelf region (Table 4). To compare these recent consumption estimates with those from the early $1980 \mathrm{~s}$, a period of low jellyfish biomass, we approximated the biomass for the early time period by adjusting the 1999 Methot catches by the catch differences (38-fold) between 1982 and 1999 for the Pribilof Region (Fig. 3). We estimated that, for 1982, C. mela-

Table 4. Chrysaora melanaster. Calculations of food consumption using biomass data for the summer of 1999 compared with estimates of standing stocks and production of zooplankton on the eastern Bering Sea middle shelf. Also shown are estimates of juvenile pollock consumption compared to standing stocks

\begin{tabular}{|c|c|c|c|c|c|}
\hline Data & Mean & $\begin{array}{c}95 \% \text { Con } \\
\text { lower }\end{array}$ & $\begin{array}{l}\text { dence lim } \\
\text { upper }\end{array}$ & $\begin{array}{c}\text { its Conversion } \\
\%\end{array}$ & Source \\
\hline \multicolumn{6}{|c|}{ Chrysaora melanaster biomass and consumption } \\
\hline Wet wt $\left(\mathrm{g} \mathrm{m}^{-2}\right)$ & 114.9 & 49.6 & 180.2 & & 'Oshoro Maru' summer data \\
\hline Dry wt $\left(\mathrm{g} \mathrm{m}^{-2}\right)$ & 3.8 & 1.6 & 5.9 & $3.3 \mathrm{WW}$ & Shenker (1985) for C. fuscescens \\
\hline Carbon $\left(\mathrm{g} \mathrm{m}^{-2}\right)$ & 0.3 & 0.1 & 0.4 & $7.22 \mathrm{DW}$ & Larson (1986) \\
\hline Daily ration $\left(\mathrm{g} \mathrm{C} \mathrm{m}^{-2}\right)$ & 0.01 & 0.00 & 0.02 & $3.36 \mathrm{BW} \mathrm{d}^{-1}$ & Martinussun \& Båmsted (1995) ${ }^{\mathrm{a}}$ \\
\hline Summer ration $\left(\mathrm{g} \mathrm{C} \mathrm{m}^{-2}\right)$ & 0.9 & 0.4 & 1.4 & & Multiply daily ration by $90 \mathrm{~d}$ \\
\hline \multicolumn{6}{|l|}{ Zooplankton available } \\
\hline Summer biomass $\left(\mathrm{g} \mathrm{m}^{-2}\right)$ & 69.4 & 49.9 & 89.0 & & 'Oshoro Maru' plankton data (1999) \\
\hline Biomass dry wt $\left(\mathrm{g} \mathrm{m}^{-2}\right)$ & 6.9 & 5.0 & 8.9 & $10 \mathrm{WW}$ & Average from Postel et al. (2000) \\
\hline Carbon dry wt $\left(\mathrm{g} \mathrm{C} \mathrm{m}^{-2}\right)$ & 2.8 & 2.0 & 3.6 & $40 \mathrm{DW}$ & Larson (1986). Postel et al. (2000) \\
\hline \multicolumn{6}{|c|}{ Standing stock and production consumed } \\
\hline Percent consumed daily & 0.4 & 0.2 & 0.6 & & \\
\hline Percent consumed seasonally & 31.9 & 13.8 & 50.1 & & \\
\hline Percent production consumed & 4.7 & 2.0 & 7.3 & $19.0 \mathrm{~g} \mathrm{C} \mathrm{m}^{-2} \mathrm{yr}^{-1}$ & Springer et al. (1996) \\
\hline \multicolumn{6}{|l|}{ Juvenile pollock consumed } \\
\hline C. melanaster densities (ind. $\mathrm{m}^{-2}$ ) & 0.8 & 0.4 & 1.1 & & 'Oshoro Maru' Methot data \\
\hline Daily consumption (ind. $\mathrm{m}^{-2}$ ) & 0.1 & 0.1 & 0.2 & & Stomach incidence \\
\hline Pollock densities (ind. $\mathrm{m}^{-2}$ ) & 4.6 & 2.9 & 6.3 & & 'Oshoro Maru' Methot data \\
\hline Percent consumed daily & 2.8 & 4.4 & 2.0 & & Using mean consumption \\
\hline
\end{tabular}


naster seasonal consumption was $<1 \%$ of the zooplankton standing stock available that year (Napp et al. 2002).

Although each individual Chrysaora melanaster consumed on average $<1$ pollock per day (assuming only 1 meal per day), relatively high jellyfish densities (on the same order as those of pollock) led to very high consumption estimates (Table 4). For 1999, we estimated that this species alone could consume $2.8 \%$ of the pollock stock per day around the Pribilof Islands during the latter part of July.

We suggest that our food consumption estimates based on carbon demand by Chrysaora melanaster should be taken only as first-order approximations, given that there are many uncertainties associated with our estimates and the sources of model parameters. For example, our diet analysis was very limited in space and time and was comprised of a relatively small number of specimens. The medusae used were damaged by the trawl nets, losing their oral feeding lobes in the process, so that additional prey items lodged in the oral arms were undoubtedly lost at the time of collection. Our daily ration estimates were taken from another species, and we were not able to evaluate the confounding effects of predator size, prey type, and temperature on daily ration (Båmstedt \& Martinussen 2000).

\section{Potential causes of jellyfish increases}

We do not know with certainty what has caused the biomass of jellyfishes to increase in recent decades. In

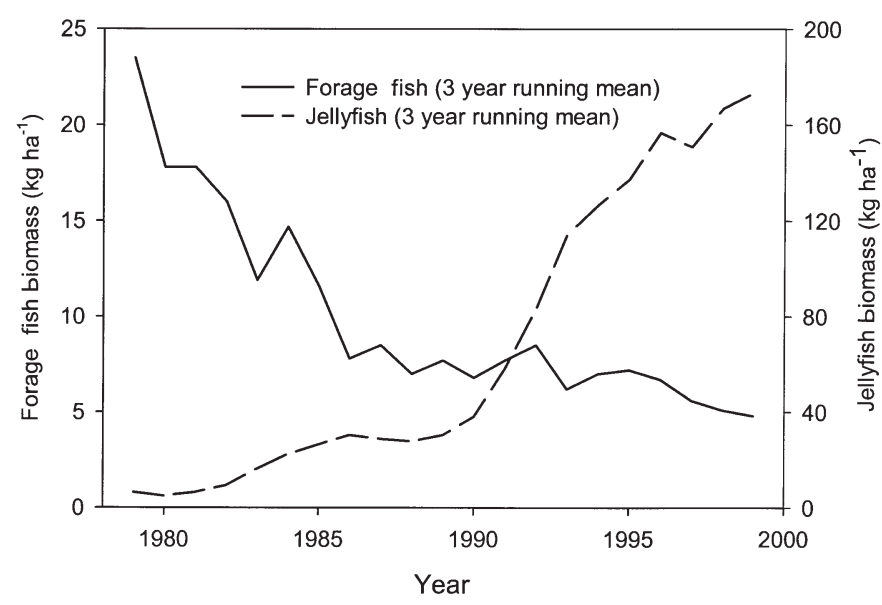

Fig. 11. Time series of the combined forage fish and jellyfish biomass (both 3 yr running means) based on summer bottomtrawl surveys on eastern Bering Sea shelf. (See Brodeur et al. [1999b] and Hunt et al. [2001] for description of sampling methodology for these catches) a previous paper (Brodeur et al. 1999a), it was suggested that environmental forcing through climate change could have been a driving factor. This was based on the timing of the onset of the increase around 1989, which has been identified as period of change in atmospheric/oceanographic regimes in the north Pacific (Hare \& Mantua 2000). The greater ice extent over the SE Bering Sea in the years subsequent to this regime shift may have led to a more stable and productive surface layer following the spring ice retreat (Hunt et al. 2002). The stable water column would also be associated with the warmer surface layer in summer observed in the 1990s, which might be conducive to jellyfish growth and survival. However, this trend was at least temporarily halted in the summer of 1999, which exhibited the lowest surface temperatures by far since the bottom trawl survey was initiated in the mid1970s (G. Walters, Alaska Fisheries Science Center, unpubl. data). Despite these cold temperatures, the biomass of jellyfishes continued to be high that summer, and in fact was the second highest of the whole series. The size of individual Chrysaora melanaster, the dominant species, was also at least as large as in the previous few years, which would indicate that these individuals were not temperature-limited in their growth. One potential explanation for this paradox is that some individuals may have survived the winter as large medusae rather than as the attached benthic stage. Support for this comes from catches of large ( $>10 \mathrm{~cm}$ bell diameter) C. melanaster during a cruise in the SE Bering Sea in mid-February of 1999. It had been assumed that this species does not live longer than $1 \mathrm{yr}$ in the Bering Sea, but because of the paucity of winter sampling in this region, it is uncertain whether this is a rare occurrence.

Alternatively, the increase in jellyfishes may have resulted from a release from competition with Age 1 pollock, juvenile herring Clupea pallasi, and capelin Mallotus villosus for zooplankton resources. Indeed, there is a significant $(r=-0.69 ; \mathrm{p}=0.005)$ inverse relationship between the biomass of jellyfishes and the summed biomass of these forage fishes on the eastern Bering Sea shelf over the last 2 decades (Fig. 11). The rapid increase in jellyfish biomass followed the decline of Age 1 pollock and other forage fishes in each region of the SE Bering Sea by 3 to 7 yr (Hunt et al. 2002).

Recent work has shown that the productivity of an ecosystem can affect the relative importance of competition and predation in determining community structure and species abundances (Holt et al. 1994, Leibold 1996, Bohannan \& Lenski 2000). When resources are in short supply, competition is predicted to have the more important influence, whereas when production is high, predation plays a more important role in structuring 
the ecosystem. In the SE Bering Sea, it is thought that water temperature plays the most important role in determining zooplankton production, with periods of warmer temperatures having higher production (Hunt et al. 2002). Prior to the regime shift in 1976, water temperatures in spring and summer were cooler than they have been since (Hunt et al. 2002). If zooplankton production has been higher since the regime shift, then in the SE Bering Sea there may have been a shift in the community structure. In the cold years, competition may have played the most important role in partitioning zooplankton resources between jellyfishes and the dominant pelagic forage fishes such as Age 1 pollock. However, with warming temperatures and increased zooplankton availability, ability to avoid predation may have become of paramount importance. Predation would have been particularly severe for Age 0 and Age 1 pollock, as during this period the biomass of older cannibalistic pollock increased substantially, and the system apparently became top-down controlled (Hunt et al. 2002). Under these circumstances, with plentiful food, generally warmer water temperatures that promote rapid growth, and a lack of competitors or significant predators, jellyfish biomass could increase exponentially.

What then does limit jellyfish biomass in the Bering Sea? In some ways, it is an ideal habitat for cnidarians. The broad continental shelf provides ample habitat for development of the benthic polyp stage, although their precise field habitat has not been established in the Bering Sea. The relatively shallow water column and sluggish currents on the shelf combined with high standing stocks and production of zooplankton are conducive to producing a high biomass. Jellyfishes can reproduce both sexually and asexually, which can further lead to a rapid increase in population size. Other than seabirds (Harrison 1984) and other jellyfishes (Hamner 1983, and present study) consuming smaller individuals, we know of no other abundant predators on these medusae. Some fish predators, including adult pollock, are known to prey on jellyfishes in both the Bering Sea (Geoff Lang, Alaska Fisheries Science Center, pers. comm.) and elsewhere (see review by Purcell \& Arai 2001), but the occurrence of gelatinous prey is low compared to other prey types. The rapid digestion of these gelatinous forms, however, may limit our ability to detect them in the stomachs of most fishes (M. Arai, Department of Fisheries and Oceans, Nanaimo, Canada, pers. comm.). In addition, by late summer many medusae are likely to grow large enough to escape predation by most marine organisms. Thus, once a jellyfish population is established, it may remain in place until it becomes self-limiting or until the environment shifts to less favorable conditions.

\section{CONCLUSIONS}

From the results of isotope ratios and stomach content analysis, it was found that Chrysaora melanaster and juvenile pollock share similar diets. C. melanaster also prey on macrozooplankton that are prey of adult pollock, which means that $C$. melanaster utilizes organic matter that would be available to pollock. Therefore, high abundance of $C$. melanaster may affect the biomass of pollock through competition for prey. In addition, based on our pollock consumption estimates, a substantial feeding pressure by $C$. melanaster on the early life stages of pollock was shown for the area around the Pribilof Islands in midsummer. The inverse relationship between the biomass of forage fishes and jellyfishes suggests the possibility of a competitive interaction. We suggest that climate change may affect the interaction between jellyfishes and other elements of the eastern Bering Sea ecosystem, and that, at present, jellyfishes may be increasing at the expense of other species, including the commercially important walleye pollock.

Our calculations do suggest that Chrysaora melanaster can be an important consumer and may depress the zooplankton standing stocks on a local scale. Clearly, more detailed laboratory and field studies are needed to quantify the vital rates (feeding, growth, reproduction) of this important species. More data need to be collected during the late spring, which may be a period of high growth rate and food consumption. As these data become available, more detailed dynamic simulation modeling could be undertaken to elucidate the effect this increase has had on the entire ecosystem. Finally, food consumption and predation impact studies should be attempted on finer spatial and temporal scales than we were able to accomplish because of the inherent patchiness of both jellyfishes and their prey species in this system.

Acknowledgements. We are grateful to the captain, officers, crew, and scientists on board the RV 'Miller Freeman' and RV 'Oshoro Maru' for their cooperation in sampling at sea. In particular, we would like to thank Morgan Busby, Lorenzo Ciannelli, Steve DeBlois, Bill Floering, Kevin Landgraf, Bill Rugen, and Matt Wilson for their seemingly endless measuring of jellyfish diameters. Gary Walters of the Alaska Fisheries Science Center generously provided data on jellyfish catches from the groundfish surveys. Steve Syrjala assisted with the statistical analysis. Claudia Mills of the University of Washington assisted with the identification of jellyfishes in the trawls and ROV videos. We wish to thank Sam Wainright and Keith Bosley of Rutgers University and T. Ichikawa of the National Research Institute of Fisheries Science of Japan for allowing us to use their mass spectrometers and in their help with operating the machines. Previous versions of the manuscript benefited from the helpful comments given by Mary Arai, Kerim Aydin, J. Claudia Mills, Jenny Purcell, Jeff Napp, Cynthia 
Tynan, and an anonymous reviewer. H.S. acknowledges the Japanese STA Fellowship for funding his stay in the US. This study was funded in part by NOAA's Coastal Ocean Program under the SE Bering Sea Carrying Capacity project, and is Contribution Number FOCI-S411 of NOAA's Fisheries Oceanography Coordinated Investigations.

\section{LITERATURE CITED}

Arai MN (1988) Interactions of fish and pelagic coelenterates. Can J Zool 66:1913-1927

Arai MN (1997) A functional biology of scyphozoa. Chapman \& Hall, London

Båmstedt U, Martinussen MB (2000) Estimating digestion rate and the problem of individual variability, exemplified by a scyphozoan jellyfish. J Exp Mar Biol Ecol 251:1-15

Behrends G, Schneider G (1995) Impact of Aurelia aurita medusae (Cnidaria, Scyphozoa) on the standing stock and community composition of mesozooplankton in the Kiel Bight (western Baltic Sea). Mar Ecol Prog Ser 127:39-45

Berdnikov SV, Selyutin VV, Vasilchenko VV, Caddy JF (1999) Trophodynamic model of the Black and Azov Sea pelagic ecosystem: consequences of the comb jelly, Mnemiopsis leydei, invasion. Fish Res (Amst) 42:261-289

Bohannan BJM, Lenski RE (2000) The relative importance of competition and predation varies with productivity in a model community. Am Nat 156:329-340

Brodeur RD (1998) In situ observations of the associations of juvenile fishes and scyphomedusae in the eastern Bering Sea. Mar Ecol Prog Ser 163:11-20

Brodeur RD, Mills CE, Overland JE, Walters GE, Schumacher JD (1999a) Substantial increase in gelatinous zooplankton in the Bering Sea, with possible links to climate change. Fish Oceanogr 8:296-306

Brodeur RD, Wilson MT, Walters GE, Melnikov IV (1999b) Forage fishes in the Bering Sea: distribution, species associations, and biomass trends. In: Loughlin TR, Ohtani K (eds) Dynamics of the Bering Sea. Sea Grant AK-SG99-03, University of Alaska, Fairbanks, p 509-536

Brodeur RD, Wilson MT, Ciannelli L, Doyle M, Napp JM (2002) Interannual and regional variability in distribution and ecology of juvenile pollock and their prey in frontal structures of the Bering Sea. Deep-Sea Res II (in press)

DeNiro, MJ, Epstein S (1977) Mechanism of carbon isotope fractionation associated with lipid synthesis. Science 197: 261-263

Fancett MS (1988) Diet and prey selectivity of scyphomedusae from Port Phillip Bay, Australia. Mar Biol 98:503-509

Fancett MS, Jenkins GP (1988) Predatory impact of scyphomedusae on ichthyoplankton and other zooplankton in Port Phillip Bay. J Exp Mar Biol Ecol 116:63-77

Feigenbaum D, Kelly M (1984) Changes in the lower Chesapeake Bay food chain in the presence of the sea nettle Chrysaora quinquecirrha (Scyphomedusa). Mar Ecol Prog Ser 19:39-47

Frank KT (1986) Ecological significance of the ctenophore Pleurobrachia pileus off Southwestern Nova Scotia. Can J Fish Aquat Sci 43:211-222

Fry B, Wainright SC (1991) Diatom sources of ${ }^{13} \mathrm{C}$-rich carbon flow in marine food web. Mar Ecol Prog Ser 76:149-157

Graham WM (2001) Numerical increases and distributional shifts of Chrysaora quinquecirrha (Desor) and Aurelia aurita (Linné) (Cnidaria, Scyphozoa) in the Northern Gulf of Mexico. Hydrobiol 451:97-111

Greve W (1994) The 1989 German Bight invasion of Muggiaea atlantica. ICES J Mar Sci 51:355-358
Hamner W (1983) Gelatinous zooplankton of the Bering Sea In: Processes and resources of the Bering Sea shelf, Final Report, Vol. II. National Science Foundation, Washington, DC, p 211-229

Hamner WM, Schneider D (1986) Regularly spaced rows of medusae in the Bering Sea: role of Langmuir circulation. Limnol Oceanogr 31:171-177

Hare SR, Mantua NJ (2000) Empirical indicators for North Pacific regime shifts in 1977 and 1989. Prog Oceanogr 47: 103-146

Harrison NM (1984) Predation on jellyfish and their associates by seabirds. Limnol Oceanogr 29:1335-1337

Holt RD, Grover J, Tilman D (1994) Simple rules for interspecific dominance in systems with exploitative and apparent competition. Am Nat 144:741-771

Hunt GL Jr, Stabeno P, Walters G, Sinclair E, Brodeur RD, Napp JM, Bond NA (2002) Climate change and control of the southeastern Bering Sea pelagic ecosystem. Deep-Sea Res II (in press)

Huntley ME, Hobson LA (1978) Medusae predation and plankton dynamics in a temperate fjord, British Columbia. J Fish Res Board Can 35:257-261

Ikeda T (1974) Nutritional ecology of marine zooplankton. Mem Fac Fish Hokkaido Univ 22:1-97

Kovalev AV, Piontkovski SA (1998) Interannual changes in the biomass of the Black Sea gelatinous zooplankton. J Plankton Res 20:1377-1385

Larson RJ (1986) Water content, organic content, and carbon and nitrogen composition of medusae from the northeast Pacific. J Exp Mar Biol Ecol 99:107-120

Leibold MA (1996) A graphical model of keystone predators in food webs: trophic regulation of abundance, incidence, and diversity patterns in communities. Am Nat 147: $784-812$

Loughlin TR, Ohtani K (1999) Dynamics of the Bering Sea. Alaska Sea Grant Program Publ Sea Grant AK-SG-99-03. University of Alaska, Fairbanks, p 1-840

Malej A, Faganeli J, Pezdič J (1993) Stable isotope and biochemical fractionation in the marine pelagic food chain: the jellyfish Pelagia noctiluca and net zooplankton. Mar Biol 116:565-570

Martinussen MB, Båmstedt U (1995) Diet, estimated food ration and predator impact by the scyphozoan jellyfishes Aurelia aurita and Cyanea capillata. In: Skjoldal HR, Hopkins C, Erikstad KE, Leinaas HP (eds) Ecology of fjords and coastal waters. Elsevier Science, New York, p 127-145

Matsakis S, Conover RJ (1991) Abundance and feeding of medusae and their potential impact as predators on other zooplankton in Bedford Basin (Nova Scotia, Canada) during spring. Can J Fish Aquat Sci 48:1419-1430

McConnaughey T, McRoy CP (1979) Food web structure and the fractionation of carbon isotopes in the Bering Sea. Mar Biol 53:257-262

Methot RD (1986) A frame trawl for sampling juvenile fish. CALCOFI (Cal Coop Ocean Fish Investig) Rep 27:267-278

Michener RH, Schell DM (1994) Stable isotope ratios as tracers in marine aquatic food webs. In: Lajtha $\mathrm{K}$, Michener $\mathrm{RH}$ (eds) Stable isotopes in ecology and environmental science. Blackwell Science, London, p 138-157

Mills CE (1995) Medusae, siphonophores, and ctenophores as planktivorous predators in changing global ecosystems. ICES J Mar Sci 52:575-581

Mills CE (2001) Jellyfish blooms: are populations increasing globally in response to changing ocean conditions? Hydrobiologia 451:55-68

Möller H (1984) Reduction of a larval herring population by jellyfish predator. Science 224:621-622 
Napp JM, Hunt GL Jr (2001) Anomalous conditions in the SE Bering Sea, 1997: linkages among climate, weather, ocean, and biology. Fish Oceanogr 10:61-68

Napp JM, Baier CT, Coyle KO, Brodeur RD, Shiga N, Mier K (2002) Interannual and decadal variability in zooplankton communities of the SE Bering Sea shelf. Deep-Sea Res II (in press)

National Research Council (1996) The Bering Sea ecosystem. National Academy Press, Washington, DC

Olson MB, Strom SL (2002) Phytoplankton growth, microzooplankton herbivory and community structure in the SE Bering Sea: insight into the formation and temporal persistence of an Emiliania huxleyi bloom. Deep-Sea Res II (in press)

Omori M (1969) Weight and chemical composition of some important oceanic zooplankton in the north Pacific Ocean. Mar Biol 3:4-10

Omori M, Ishii H, Fujinaga A (1995) Life history strategy of Aurelia aurita (Cnidaria, Scyphomedusae) and its impact on the zooplankton community of Tokyo Bay. ICES J Mar Sci 52:597-603

Pagès F, González HE, González SR (1996) Diet of the gelatinous zooplankton in Hardangerfjord (Norway) and potential predatory impact by Aglantha digitale (Trachymedusae). Mar Ecol Prog Ser 139:69-77

Postel L, Fock H, Hagen W (2000) Biomass and abundance. In: Harris R, Wiebe P, Lenz J, Skjoldal HR, Huntley M (eds) ICES Zooplankton methodology manual. Academic Press, London, p 85-192

Purcell JE (1985) Predation on fish eggs and larvae by pelagic cnidarians and ctenophores. Bull Mar Sci 37:739-755

Purcell JE (1989) Predation on fish larvae and eggs by the hydromedusa Aequorea victoria at a herring spawning ground in British Columbia. Can J Fish Aquat Sci 46: 1415-1427

Purcell JE (1992) Effects of predation by the scyphomedusan Chrysaora quinquecirrha on zooplankton populations in Chesapeake Bay, USA. Mar Ecol Prog Ser 87:65-76

Purcell JE (1997) Pelagic cnidarians and ctenophores as predators: selective predation, feeding rates, and effects on prey populations. Ann Inst Océanogr 73:125-137

Purcell JE, Arai MN (2001) Interactions of pelagic cnidarians and ctenophores with fish: a review. Hydrobiologia 451:27-44

Purcell JE, Sturdevant MV (2001) Prey selection and dietary overlap among zooplanktivorous jellyfish and juvenile fishes in Prince William Sound, Alaska. Mar Ecol Prog Ser 210:67-83

Purcell JE, Siferd TD, Marliave JB (1987) Vulnerability of larval herring (Clupea harengus pallasi) to capture by the jel-

Editorial responsibility: Jennifer Purcell (Contributing

Editor), Anacortes, Washington, USA lyfish Aequorea victoria. Mar Biol 94:157-162

Purcell JE, White JR, Roman MR (1994) Predation by gelatinous zooplankton and resource limitation as potential controls of Acartia tonsa copepod populations in Chesapeake Bay. Limnol Oceanogr 39:263-278

Purcell JE, Malej A, Benović A (1999) Potential links of jellyfish to eutrophication and fisheries. Coast Estuar Stud 55: p 241-263

Schell DM, Barnett BA, Vinette KA (1998) Carbon and nitrogen isotope ratios in zooplankton of the Bering, Chukchi, and Beaufort seas. Mar Ecol Prog Ser 162:11-23

Schneider G, Behrends G (1994) Population dynamics and the trophic role of Aurelia aurita medusae in the Kiel Bight and western Baltic. ICES J Mar Sci 51:359-367

Schumacher JD, Bond NA, Brodeur RD, Livingston PA, Napp JM, Stabeno PJ (2002) Climate change in the SE Bering Sea and some consequences for biota. In: Hempel G, Sherman K (eds) Large marine ecosystems of the world: trends in exploitation, protection and research. Elsevier Science, Amsterdam (in press)

Shenker JM (1985) Carbon content of the neritic scyphomedusae Chrysaora fuscescens. J Plankton Res 7:169-173

Shiganova TA (1998) Invasion of the Black Sea by the ctenophore Mnemiopsis leidyi and recent changes in pelagic community structure. Fish Oceanogr 7:305-310

Shiganova TA, Bulgakova YV (2000) Effects of gelatinous plankton on Black Sea and Sea of Azov fish and their food resources. ICES J Mar Sci 57:641-648

Smith S, Heinrichs SM (2002) Stable C and N isotopic composition of sinking particles and zooplankton over the SE Bering Sea shelf. Deep-Sea Res II (in press)

Springer AM (1992) A review: walleye pollock in the north Pacific - how much difference do they really make? Fish Oceanogr 1:80-96

Springer AM, McRoy PC, Flint MV (1996) The Bering Sea Green Belt: shelf-edge processes and ecosystem production. Fish Oceanogr 5:205-223

Stockwell DA, Whitledge TE, Zeeman SI, Coyle KO, Napp JM, Brodeur RD, Pinchuk AI, Hunt GL Jr (2001) Anomalous conditions in the SE Bering Sea, 1997: nutrients, phytoplankton, and zooplankton. Fish Oceanogr 10: 99-116

Sugisaki H, Brodeur RD, Napp JM (1998) Summer distribution and abundance of macrozooplankton in the western Gulf of Alaska and SE Bering Sea. Mem Fac Fish Hokkaido Univ 45:96-112

Syrjala SE (1996) A statistical test for a difference between the spatial distributions of two populations. Ecology 77:75-80

Zaitsev YP (1992) Recent changes in the trophic structure of the Black Sea. Fish Oceanogr 1:180-189

Submitted: April 27, 2001; Accepted: October 14, 2001

Proofs received from author(s): April 22, 2002 